\title{
FEATURES OF THE INTERCONNECTION BETWEEN SELF-ESTEEM AND BEHAVIORAL COMPONENT OF "I-CONCEPT" OF PERSONALITY WITH ANOMALY OF REFRACTION (ON THE EXAMPLE OF MYOPIA)
}

\author{
*Gulyi Y. I., Nauchytel O. D., Dolgopolova O. V. \\ National Aerospace University KhAI, Chkalov str., 17, Kharkiv, 61070, Ukraine \\ *E-mail: gyip@ukr.net, https://orcid.org/0000-0001-6035-8811
}

Received 11 July 2018

Problem statement. In modern studies, the question of structural features of "I-concept" of adult person with anomaly of refraction remains relevant.

Problem analysis. In psychological literature, the topic of the interconnection between self-esteem and the behavioral component of "I-concept" of adult person with anomaly of refraction (on the example of myopia) is not covered enough.

The purpose of the study - to reveal the features of this interconnection.

Research methods. Testing: inquirer LSI (R. Plutchik, H. Kellerman \& H. R. Conte), method of the quantitative evaluation of selfesteem (by S. A. Budassi), method of diagnostics of person's tendency to conflict behavior (K. Thomas, adaptation of N.V. Gryshyna), Taylor Manifest Anxiety Scale (adaptation of V. G. Norakidze). Statistical processing of testing data: f-criterion and factor analysis.

Description of the sample: 50 persons (31 women and 19 men), 25 - without visual impairment, and 25 - with myopia.

Research results. The anomaly of refraction (on the example of myopia) affects certain features of the behavioral component of "Iconcept" of personality. Personality with myopia prefers the psychological defense mechanism "negation", when regulating conflicts, it often refers to "collaborating".

The study of the interconnections between the test indicators revealed a wider, varied and contradictory nature of these connections in the group of persons with myopia.

Conclusions. The nature of the interconnection between self-esteem and the behavioral component of "I-concept" of personality with anomaly of refraction (on the example of myopia) is determined by the following features.

The activation of the psychological defense mechanism "rationalization" contributes to increase of self-esteem, stimulates the mechanisms of "displacement" and "compensation", which has a certain influence on the choice of "collaborating" as the dominant conflict-handling mode. The above features are accompanied by a certain complication (contradiction) of the behavioral component of "I-concept".

The results obtained can be useful in conducting counseling work with people who have anomaly of refraction.

KEY WORDS: personality, "I-concept", self-esteem, anomaly of refraction, myopia, anxiety, psychological defense mechanism, conflict-handling mode.

\section{ОСОБЛИВОСТІ ВЗАСМОЗВ'ЯЗКУ САМООЦІНКИ І ПОВЕДІНКОВОЇ СКЛАДОВОЇ «Я-КОНЦЕПЦЇ̈» ОСОБИСТОСТІ З АНОМАЛІЄЮ РЕФРАКЦІЇ (НА ПРИКЛАДІ КОРОТКОЗОРОСТІ)}

Гулий Ю. І., Научитель О. Д., Долгополова О. В. Кафедра психології Національного аерокосмічного університету ім. М.Є. Жуковського «Харківський авіаційний інститут» 61070, Харків-70, вул. Чкалова, 17

Постановка проблеми. В сучасних дослідженнях залишається актуальним питання щодо структурних особливостей «Яконцепції» дорослої людини з аномалією рефракції.

Аналіз проблеми. В психологічній літературі тема взаємозв'язку між самооцінкою та поведінковою складовою «Я-концепції» дорослої людини з аномалією рефракції (на прикладі короткозорості) висвітлена недостатньо.

Мета дослідження - виявити особливості цього взаємозв'язку.

Методи дослідження. Тестування: опитувальник LSI Плутчика-Келлермана-Конте, методика кількісного вимірювання самооцінки (С. А. Будассі), методика діагностики схильності особистості до конфліктної поведінки (К. Томаса, адаптація Н. В. Гришиної), методика вимірювання рівня тривожності (Дж. Тейлора, адаптація В. Г. Норакідзе). Статистична обробка даних: f-критерій та факторний аналіз.

Опис вибірки: 50 осіб (31 жінка і 19 чоловіків), 25 - без порушення зору, у 25-ти - міопія.

Результати дослідження. Аномалія рефракції (на прикладі короткозорості) позначається на певних особливостях поведінкової складової «Я-концепції» особистості. Особистість з короткозорістю віддає перевагу механізму психологічного захисту «заперечення», а при здійсненні регулювання конфліктів частіше звертається до «співробітництва».

Вичення взаємозв'язків між показниками тестування виявило більш широкий, різноманітний і суперечливий характер цих зв'язків у групі особистостей з короткозорістю.

(C Гулий Ю. І., Научитель О. Д., Долгополова О. В., 2018 
Висновки. Характер взаємозв'язку самооцінки і поведінкової складової «Я-концепції» особистості з аномалією рефракції (на прикладі короткозорості) визначається наступними особливостями.

Активізація механізму психологічного захисту «раціоналізація» сприяє підвищенню самооцінки, стимулює механізми «витіснення» і «компенсації», що має певний вплив на вибір «співробітництва» як домінуючого способу регулювання конфліктів. Названі особливості супроводжуються певним ускладненням (суперечливістю) поведінкової складової «Яконцепції».

Одержані результати можуть бути корисними при здійсненні консультаційної роботи 3 людьми, що мають аномалію рефракції.

КЛЮЧОВІ СЛОВА: особистість, «Я-концепція», самооцінка, аномалія рефракції, короткозорість, тривожність, механізм психологічного захисту, спосіб регулювання конфліктів.

Постановка проблеми. «Я-концепція» $€$ цілісним утворенням, динамічною системою уявлень людини про себе. Вона формується під впливом індивідуального досвіду і становить основу вищої саморегуляції людини, на базі якої будуються стосунки з оточуючим світом.

Дослідженням проблематики «Я-концепції» (iї змістовних, структурних особливостей тощо) займались А. Адлер, Р. Бернс, У. Джеймс, Е. Еріксон, К. Роджерс, В. П. Зінченко, І. С. Кон, В. В. Столін та ін.

Серед низки різних дослідницьких підходів щодо структури «Я-концепції» нвйбільш поширеним є підхід, в якому виділяють когнітивну, оцінну і поведінкову складові «Я-концепції» [2]. Когнітивна складова - це уявлення індивіда про самого себе (низка характеристик, якими, як йому здається, він володіс). Оцінна складова (багато в чому визначається самооцінкою) - це те, як індивід оцінює ці характеристики, як до них ставиться. Поведінкова складова включає потенційні поведінкові реакції або конкретні дії, які можуть бути викликані знаннями про себе і що особливо важливо - ставленням до себе (самооцінкою особистості). При цьому «Я-концепція», маючи відносну стабільність, обумовлює досить стійкі схеми поведінки людини (за К. Роджерсом), а всі ії складові хоча і мають відносну самостійність, тісно взаємопов'язані [2].

В свою чергу, у контексті проблематики структури «Я-концепції» особистості $з$ аномалією рефракції (на прикладі короткозорості) на сьогоднішній день найбільш розробленим є питання щодо особливостей «Я-концепції» школярів 3 короткозорістю $[1,3,4,5$ та ін.]. При цьому недостатньо висвітленим залишається питання щодо стуктурних особливостей «Я-концепції» (зокрема взаємозв'язку її складових) у дорослої людини з короткозорістю.

Аналіз проблеми. Міопія досконально досліджена як медичний феномен, проте недостатньо вивчена 3 точки зору психології. До недавнього часу вивчення міопії було сконцентровано на фізіологічному аспекті, теорія виникнення і розвитку цього захворювання розроблялась переважно в офтальмології.

В даний час міопія розглядається як комплексний феномен в рамках біомедичного напряму (зоровий аналізатор як частина цілісного організму, вплив генетичних факторів тощо), проте іï соціальнийі, культурний та психологічний аспекти все ще потребують окремих досліджень.

У лонгітюдному досліджені $\quad$ В. М. Петухова и $\quad$ О. В. Медведєва щодо особливостей виникнення і прогресування шкільної короткозорості в умовах навчального процесу були виділені також психологічні характеристики дітей з міопією. Це перфекціонізм, високий рівень особистісної тривожності, поведінкові реакції самозвинувачення, обмеження соціальних контактів, уникнення реакції засудження, конфлікти в сімейній та шкільній сферах [5].

О. О. Дорошева та Т. О. Ріппінен порівнювали Я-образи підлітків із короткозорістю та підлітків без зорових порушень. Автори роблять висновок про існування внутрішньоособистісного конфлікту у підлітків з короткозорістю, оскільки у їх Я-образі існує значна дистанція між Яідеальним і Я-реальним, а також спостерігається загальна напруженість механізмів психологічного захисту, особливо у дівчат. Крім того, самосприйняття короткозорих дівчат є менш адекватним. У цілому отримані результати вказують на існування у короткозорих дівчат внутрішньоособистісного 
конфлікту, пов'язаного з незадоволеною потребою прийняття оточуючими [4].

Узагальнюючи результати, отримані для юнаків і дівчат, у якості загального діючого чинника автори виділяють страх невдачі. У короткозорих підлітків присутня тенденція до уникнення невдач у міжособистісних відносинах. Мотивація до уникнення невдач у різних сферах в цілому більш характерна для дівчат, тоді як для юнаків домінуючий мотив - прагнення до успіху. Таким чином, найбільш проблемною для підлітків є сфера міжособистісних відносин. Вони бояться бути неприйнятими. Дівчата намагаються впоратися 3 цим страхом, знизивши негативні тенденції поведінки, ставши менш агресивними, менш критичними до інших При цьому у них зберігається високий рівень психічної напруги. Юнаки прагнуть вирішити цю проблему за допомогою соціальної ізоляції [4].

У дослідженні офтальмогів М. О. Черепахіної, О. Г. Рибакової та К. Г. Гуревича встановлено, що зі зростанням ступеня міопії достовірно знижується рівень якості життя у пацієнтів, в який включаються рівень психологічного комфорту, залежність від оточуючих, рольові труднощі та труднощі у спілкуванні. Автори зазначають, що ступіть міопії більше всього впливає на сферу психічних і соціальних функцій пацієнта. особливо виражене статистично достовірне зниження рівня якості життя було зареєстровано у пацієнтів з високим ступенем міопії [6].

Попри описані дослідження, до сих пір у психологічній літературі тема стуктури «Яконцепції» (зокрема взаємозв'язку іiі складових) у дорослої особистості 3 аномалією рефракції висвітлена недостатньо.

Базуючись на основних положеннях щодо стуктури «Я-концепції», викладених при постановці проблеми на початку статті, можна визначити найбільш значущі (у діяльнісному аспекті) особливості названої структури.

Найважливішою функиією «Я-кониепиіï» $є$ забезпечення внутрішньої узгодженості особистості, відносної стійкості іiі поведінки (поведінкова складова). Якщо новий досвід, отриманий індивідом, узгоджується 3 існуючими уявленнями про себе, він легко асимілюється 3 «Яконцепцією». Якщо ж новий досвід не вписується в уявлення про себе, суперечить вже наявній «Яконцепції», то спрацьовують механізми психологічного захисту, які допомагають особистості тенденційно інтерпретувати травмуючий досвід або заперечувати його. Це дозволяє утримувати «Я-

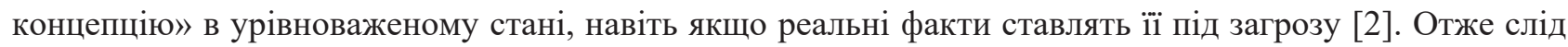
акцентувати увагу на поведінковій складовій «Я-концепції», а саме - механізмах психологічного захисту особистості (у нашому випадку - з аномалією рефракції).

Оскільки поведінкова складова багато в чому обумовлюється самооцінкою особистості, то треба зробити на останній акцент як на засадничому чиннику оцінної складової «Я-концепції».

У свою чергу, неадекватна самооцінка призводить до негативних наслідків, часто супроводжується соціальною дезадаптацією особистості, створює грунт як для внутрішньоособистісних, так і міжособистісних конфліктів (стосується поведінкової складової), тобто виникає необхіднісить визначення схильності особистості до конфліктної поведінки, яка вияввляється через способи регулювання конфліктів. Безумовно, що в цьому контексті можливих суперечностей в "Я-концепції" треба обов'яззково відзначити тривожність як базовий прояв цих суперечностей [2].

Мета дослідження - виявити особливості взаємозв'язку самооцінки і поведінкової складової «Я-концепції» особистості з аномалією рефракції (на прикладі короткозорості).

Методи дослідження. Тестування: опитувальник «Індекс життєвого стилю (LSI)» ПлутчикаКеллермана-Конте; методика кількісного вимірювання самооцінки (С. А. Будассі), методика діагностики схильності особистості до конфліктної поведінки (К. Томаса, адаптація Н. В. Гришиної); методика вимірювання рівня тривожності (Дж. Тейлора, адаптація В. Г. Норакідзе). Математикостатистична обробка даних тестування: f-критерій кутового перетворення Фішера та факторний 
аналіз (метод головних компонент, обертання Varimax raw).

Опис вибірки. У дослідженні взяли участь 50 осіб (31 жінка та 19 чоловіків), 25 з яких не мають порушень зору, а у 25-ти діагностовано аномалію рефракції (короткозорість).

До складу першої групи (длслідницької) увійшли клієнти мережі оптик, які мають різні ступені вираженості короткозорості. Група формувалася на основі клінічного діагнозу, який визначений у медичних картках. Усі опитані дали згоду на використання їх особистих даних. 25 осіб, із яких 16 жінок та 9 чоловіків. Середній вік - 37 років. Друга група (контрольна) - 25 осіб без вад зору, з яких 15 жінок та 10 чоловіків. Середній вік - 33,4 роки.

Результати дослідження. Після порівняння середньогрупових показників тестування двох груп досліджуваних (f-критерій) були зроблені наступні узагальнення.

Щодо показників механізмів психологічного захисту особистості. Особи з короткозорістю частіше, ніж особи без вад зору, викоростовують «заперечення».

Порівняння показників самооцінки між двома групами досліджуваних. Особистість 3 короткозорістю характеризується середнім адекватним рівнем самооцінки. Крім того, у представників цієї групи зустрічається низька адекватна та низька неадекватна самооцінка. Однак кількість спостережень не дає достатньо підстав для статистично достовірного висновку. Для особистості без зорових порушень у однаковій мірі притаманні як високий адекватний, так і середній рівні самооцінки.

Щодо способів регулювання конфліктів. Особистість 3 короткозорістю при вирішенні конфліктів частіше звертається до такої стратегії як «співпраця» і рідше - до «змагання». У конфліктних ситуаціях таким людям притаманно шукати найбільш оптимальне рішення, тобто рішення, що повністю задовольняє інтереси обох сторін.

Порівняння рівнів тривожності у двох групах дозволило виявити, що рівень тривожності особистості не пов'язаний зі станом зорового апарату. В обох групах виявлено дуже високий та високий рівні тривожності.

Для виявлення характеру взаємозв'язків між показниками тестування був застосований факторний аналіз. Відповідні факторні структури (першої та другої групи) подано в табл. 1, 2.

Таблиця 1

Факторна структура взаємозв'язку показників тестування першої групи

\begin{tabular}{|l|c|c|c|}
\hline Variable (показники тестування) & Factor 1 & Factor 2 & Factor 3 \\
\hline Витіснення & 0,534 & - & 0,638 \\
\hline Регресія & - & 0,588 & - \\
\hline Заміщення & - & - & - \\
\hline Заперечення & 0,741 & - & - \\
\hline Проекція & 0,519 & - & 0,624 \\
\hline Компенсація & - & - & 0,855 \\
\hline Гіперкомпенсація & 0,565 & - & 0,613 \\
\hline Раціоналізація & - & - & - \\
\hline Тривожність & - & 0,754 & - \\
\hline Самооцінка & - & - & 0,487 \\
\hline Змагання & - & 0,899 & - \\
\hline Компроміс & $-0,476$ & $-0,541$ & - \\
\hline Співробітництво & $-0,664$ & - & $-0,501$ \\
\hline Уникнення & - & - & \\
\hline Пристосування & 0,585 & & \\
\hline
\end{tabular}




\begin{tabular}{|l|c|c|c|}
\hline Variable (показники тестування) & Factor 1 & Factor 2 & Factor 3 \\
\hline Expl.Var & 2,6 & 2,6 & 2,4 \\
\hline Prp.Totl & 18 & 17 & 16 \\
\hline
\end{tabular}

Перший фактор біполярний. Склад першого фактору свідчить, що механізм психологічного захисту «заперечення» $(0,74)$ має прямий характер взаємозв'язку 3 такими механізмами психологічного захисту: «пристосування» $(0,58)$, «гіперкомпенсація» $(0,56)$, «витіснення» $(0,53)$ та «проекція» $(0,52)$. Стпособи регулювання конфліктів «компроміс» $(-0,48)$, «співробітництво» $(-0,66)$ виступають в якості бар'єру на шляху реалізації цих механізмів психологічного захисту i навпаки. Також можна зазначити, що домінуючий механізм психологічного захисту «заперечення» має певний вплив на активізацію механізмів «пристосування», «гіперкомпенсації», «витіснення» та «проекції». При цьому названі механізми здійснюють інтерферуючий вплив на переважаючий спосіб регулювання конфліктів «співробітництво», який супроводжується «компромісом».

Другий фактор біполярний. До складу увійшли у прямій взаємозалежності «змагання» $(0,90)$ та тривожність $(0,75)$ і «регресія» $(0,59)$. По відношенню до них в якості бар'еру виступають «компроміс» $(-0,50)$, «уникнення» $(-0,54)$ та навпаки.

Вибір способу регулювання конфліктів «змагання» активізує тривожність і «регресію», що знижує можливість застосування «компромісу» чи «уникнення» для регулювання конфліктів.

Третій фактор монополярний. У його складі у прямій взаємозалежності «раціоналізація» $(0,85)$, «компенсація» $(0,62)$, «витіснення» $(0,64)$, самооцінка $(0,613)$ та «співробітництво» $(0,49)$. Отже, «раціоналізація» може стимулювати «компенсацію», «витіснення» і підвищити самооцінку, що сприяє вибору «співробітництва» як домінуючого способу регулювання конфліктів.

Таблиця 2

Факторна структура взаємозв'язку показників тестування другої групи

\begin{tabular}{|c|c|c|c|}
\hline Variable (показники тестування) & Factor 1 & Factor 2 & Factor 3 \\
\hline Витіснення & - & 0,476 & - \\
\hline Регресія & 0,680 & - & - \\
\hline Заміщення & 0,674 & - & - \\
\hline Заперечення & - & 0,766 & - \\
\hline Проекція & 0,693 & - & - \\
\hline Компенсація & - & 0,611 & - \\
\hline Гіперкомпенсація & 0,495 & 0,498 & - \\
\hline Раціоналізація & - & 0,831 & - \\
\hline Тривожність & 0,818 & - & - \\
\hline Самооцінка & - & - & 0,648 \\
\hline Змагання & - & - & $-0,766$ \\
\hline Компроміс & - & 0,661 & - \\
\hline Співробітництво & - & - & 0,642 \\
\hline Уникнення & - & - & 0,663 \\
\hline Пристосування & 0,537 & - & - \\
\hline Expl.Var & 3,1 & 2,9 & 2,3 \\
\hline Prp.Totl & 20 & 19 & 15 \\
\hline
\end{tabular}

Перший фактор монополярний. Його склад свідчить, що показник тривожності $(0,818)$ має прямий характер взаємоз'вязку 3 «пристосуванням» $(0,54)$ і такими механізмами психологічного захисту як «регресія» $(0,68)$, «заміщення» $(0,67)$, «проекція» $(0,69)$, «гіперкомпенсація» $(0,495)$. Тривожність активує такий стпосіб регулювання конфліктів як «пристосування» i названі 
механізмами психологічного захисту.

Другий фактор також монополярний. До складу увійшли у прямій взаємозалежності механізми психологічного захисту «витіснення» $(0,476)$, «заперечення» $(0,77)$, «компенсація» $(0,61)$ «гіперкомпенсація» $(0,50)$, «раціоналізація» $(0,83)$ та стпосіб регулювання конфліктів «компроміс» $(0,66)$.

Третій фактор біполярний. До його складу у прямій взаємозалежності увійшли «спіробітництво» $(0,64)$, «уникнення» $(0,66)$ та рівень самооцінки $(0,648)$. «Змагання» $(-0,77)$ на негативному полюсі. Вибір способу регулювання конфліктів «змагання» може виступати в якості бар'єру щодо підвищення самооцінки та вибору «спіробітництва» і «уникнення» для регулювання конфліктів.

Таким чином, вичення взаємозв'язків між показниками тестування виявило більш широкий, різноманітний і суперечливий характер цих зв'язків у групі особистостей з короткозорістю.

\section{ВИСНОВКИ}

Аномалія рефракції (на прикладі короткозорості) позначається на деяких особливостях поведінкової складової «Я-концепції» особистості. Особистість з короткозорістю віддає перевагу механізму психологічного захисту «заперечення» (відмова визнавати існування чогось небажаного, психотравмуючого), при регулюванні конфліктів частіше звертається до «співробітництва» (намагання задовольнити як свої інтереси, так і інтереси протилежної сторони конфлікту).

Характер взаємозв'язку самооцінки і поведінкової складової «Я-концепції» особистості 3 аномалією рефракції (на прикладі короткозорості) визначається наступними особливостями.

Активізація механізму психологічного захисту «раціоналізація» сприяє підвищенню самооцінки, стимулює механізми «витіснення» i «компенсації», що має певний вплив на вибір «співробітництва» як домінуючого способу регулювання конфліктів.

Зазначені вище особливості супроводжуються певним ускладненням (суперечливістю) поведінкової складової «Я-концепції», а саме:

$>$ домінування механізму психологічного захисту «заперечення» активізує механізми «пристосування», «гіперкомпенсації», «витіснення» та «проекції». При цьому названі механізми мають інтерферуючий вплив на переважаючий спосіб регулювання конфліктів «співробітництво», який супроводжується «компромісом»;

$>$ вибір способу регулювання конфліктів «змагання» активізує тривожність і механізм «ренресії», що знижує можливість застосування «компромісу» чи «уникнення» для регулювання конфліктів.

У цілому, відповідь на питання, як порушення зору, викликане аномалією рефракції (короткозорістю) позначається на «Я-концепції» на пізніших етапах онтогенетичного розвитку дає змогу відповідним чином прогнозувати, які риси найбільш типово проявляються в структурі «Яконцепції» людини з міопією у зрілому віці. I це, в свою чергу, може стати в нагоді при здійсненні консультаційної (а при необхідності - і психокорекційної) роботи з людьми, що мають аномалію рефракції.

\section{СПИСОК ЛІТЕРАТУРИ}

1. Arkhireeva T. V. Системный подход к пониманию структуры Я-концепций и закономерностей ее развития в детском возрасте [A systematic approach to understanding the structure of the self-concept and the patterns of its development in childhood] // Kul'turno-istoricheskaya psikhologiya. - 2008. - no.4. - P. 48-55. (in Russian)

2. Berns R. Развитие Я-концепции и воспитание [The development of self-concept and education]. - M.: "Progress", 1986. - P. 30-66. (in Russian)

3. Dolgova V.I., Ordina I.P. Я-концепция одаренных старшеклассников [I-concept of gifted high school students: Monograph]. - Bishkek: Izd-vo «DETs», 2012. - 155 p. (in Russian) 
4. Dorosheva E.A., Rippinen T.О. Формирование образа Я у старших подростков со школьной близорукостью [Formation of the image I have in older teens with school myopia] // Vestnik NGU. Seriya: Psikhologiya, 2007. no.2. - P. 65-77. (in Russian)

5. Petukhov V.M., Medvedev A.V. Особенности возникновения и прогрессирования школьной близорукости в условиях современного учебного процесса и их профилактика [Features of the occurrence and progression of school myopia in the conditions of the modern educational process and their prevention]. - Samara: Samar. gos. med. Un-t, 2005. - P. 35-40. (in Russian)

6. Cherepakhina M.A., Rybakova E.G., Gurevich K.G. Зависимость качества жизни пациентов с миопией от степеней миопии и средства коррекции зрения [Dependence of the quality of life of patients with myopia on the degree of myopia and means of vision correction] // Klinicheskaya oftal'mologiya. Vol. 13. - no.2. - 2012. P. 70-74. (in Russian) 